\title{
Roadmap to an adaptive assembly line for e-axles
}

\author{
Muaaz Abdul Hadi $^{1}$ (D) Markus Brillinger $^{1,3} \cdot$ Franz Haas $^{1,2} \cdot$ Martin Weinzerl $^{3}$
}

Published online: 15 May 2020

(C) The Author(s) 2020

\begin{abstract}
Achieving high quality, high variety batch size production can be quite expensive. In this vision paper, the methodology of achieving this at low costs and the available technologies in the field of e-mobility production are described. The focus of this research lies in high adaptive and cognitive aspects in the assembly along with qualitative aspects. To match the high flexibility of a flexible manufacturing system while considering quantitative efforts, a use case of an e-axle assembly is being done. E-axle is chosen due to the ongoing electrification of mobility. Hence, a solution for implementing a set of methodologies for an adaptive manufacturing system with respect to assembly, quality and implementation efforts is shown. A Level of Practical Application matrix is presented of all the possible adaptive technologies that are feasible to implement in the e-assembly line.
\end{abstract}

Keywords E-mobility · Cognitive production · High variety batch production · Level of Practical Application (LoPA) . Qualitative analysis

\section{Introduction}

In the last century, researches were focussed on low-cost products and achieving them with mass production with highly efficient Dedicated Manufacturing Systems (DMS). These systems are used for manufacturing high quantities of a similar product at low throughput times. Hence, DMS are fixed and have a monotonous sequence of steps. If an additional process step for one part is required, the efficiency and quality of this system decrease significantly [1].

Now given the shift in recent years, researches are focussing on flexible manufacturing systems (FMSs) to keep pace with the ongoing mass customization. Flexible manufacturing systems are versatile and adaptive to variety of products. But, the complexity of FMS and costs of implementing such a system are quite high. Also, FMS has a lower productivity compared to DMS as the production

Muaaz Abdul Hadi

muaaz.abdul-hadi@pro2future.at

1 Pro2Future GmbH, Inffeldgasse 25F/1. OG, 8010 Graz, Austria

2 Institute of Production Engineering, Kopernikusgasse 24/I, 8010 Graz, Austria

3 AVL List, Hans-List-Platz 1, 8020 Graz, Austria steps are not conducted simultaneously [2]. The quality is of concern as the variety increases. Thus, an advantage of FMS would be that it has a vast amount of flexible automation. It is also noted that majority of users in the industry are not satisfied with the FMSs because of a variety of problems including lack of reconfigurability as a result of their fixed capacities and functionalities [3]. These are the two opposed types of manufacturing systems.

One of the challenges of the twenty-first century is the dynamic interaction between the distinct manufacturing processes and adaptability machines developed by engineers keeping the process quality of the same standards [4]. The variety in vehicle types of electromobility (e-mobility) is high and the batch size is low, which in turn makes the manufacturing and assembling costs higher [5], along with the efforts to increase quality. Thus, the manufacturers are dependent to match this high flexibility, quality and variety. To match the high flexibility of an FMS system while considering qualitative efforts, a use case of an e-axle assembly is being done. E-axle is considered as the market maturity of the electric vehicle sector is low [6]. Hence, the goal would be to implement a set of adaptive technologies for an adaptive assembly system with respect to e-mobility. Also, the focus is to achieve the right balance between the machines and humans to make the assembly process 
simpler, faster and less expensive by combining the proven methodologies.

This paper outlines the planned research in terms of investigating how the aforementioned adaptivity and quality can be achieved in an e-axle assembly. To do so, the existing process design of the assembly is analysed to identify the technological gaps. Further, to bridge this disparity, requirements of adaptive assembly system are described. Additionally, the research gap is presented by combining the benefits of these concepts and presenting the various technologies. Finally, with the help of verification models, the paper draws an outline of expected results.

\section{State of the art}

\subsection{Product and process analysis}

In the current e-axle assembly layout, a single variety of e-axle (type-B) is being assembled. However, the number of e-axles being assembled must be increased, as shown in Table 1 (three types). But the number of types can further increase over a period. Hence, our focus is to make the assembly line adaptive and error free from the current manual process. The axles can be of pure battery electric vehicle $(\mathrm{BEV})$ or an Hybrid vehicular type. For a BEV, both the front and rear sides are equipped with electric motor (e-motor). They are primarily differentiated by the number of stages and speed. Table 1 describes the differentiation of these axles in detail.
To develop an adaptive assembly system and to get a better understanding of the e-axle assembly, the assembly sequence of an existing e-axle (type-B) (as illustrated in Fig. 1) is analysed first (short overview).

The assembly sequence is an ideal case of flow or series assembly. All the parts are pre-assembled in a separate station and then moved to the assembly stations. All the tasks are performed manually. There is an end-of-line testing station which does the leakage test as well as the full-function test. Since the assembly process is completely manual, the time taken is higher. Thus, the aim is to make the assembly line adaptive thereby reducing the assembly time for this specific e-axle.

Considering the yearly output is low, which is not more than 10,000 axles/year, implementing a fully automatic assembly would not be feasible and cost-effective. As described in a case study done in [7], implementing an automated system for lower throughput per day can be expensive. Hence, a combination of completely automated system and manual tasks must be found to make the system cost-effective and adaptive [7].

For implementing these adaptive technologies, the initial Level of Automation (LoA) must be defined. The scientific approach is to perform a DYNAMO ++ methodology which further classifies into 12 steps including LoA (Level of Automation) Matrix [8-10]. This methodology helps in increasing the Level of Automation (LoA) [8]. The initial steps have been completed and the current LoA for the above e-axle assembly (type-B) has been determined, as shown in Fig. 2. In the current assembly process, there are 92 tasks which are

Table 1 Types of e-axles

\begin{tabular}{|c|c|c|c|}
\hline E-axle type & A & $\mathrm{B}$ & $\mathrm{C}$ \\
\hline Type & BEV & Hybrid & BEV \\
\hline Front & e-motor for each wheel & e-motor for each wheel & e-motor (differential used) \\
\hline Rear & e-motor for each wheel & $\begin{array}{l}\text { Internal combustion engine } \\
\text { (ICE) }\end{array}$ & e-motor (differential used) \\
\hline Speed/gear & 1 speed & 1 speed & 1 speed \\
\hline Stage & 2 stage & 1 stage & 2 stage \\
\hline Gear ratio & $14-15$ & 10 & $10-15$ \\
\hline \multirow[t]{3}{*}{ Differential } & No & No & Yes \\
\hline & 2 motors in each axle (one for each wheel) & & Bevel gear differential \\
\hline & Independent torque for each wheel & & \\
\hline Gearing & $\begin{array}{l}\text { Helical gearing-offset design (can be coaxial design as } \\
\text { well) }\end{array}$ & $\begin{array}{l}\text { Planetary gearing-coaxial } \\
\text { design }\end{array}$ & $\begin{array}{l}\text { Helical gearing—offset } \\
\text { design }\end{array}$ \\
\hline Cooling system & Water cooling in stator & Oil cooling & Oil cooling \\
\hline Parking lock & Yes & No & Yes \\
\hline $\begin{array}{l}\text { Quantity } \\
\text { required }\end{array}$ & $4000 /$ year for 3 years & $3333 /$ year for 9 years & Not specified \\
\hline
\end{tabular}




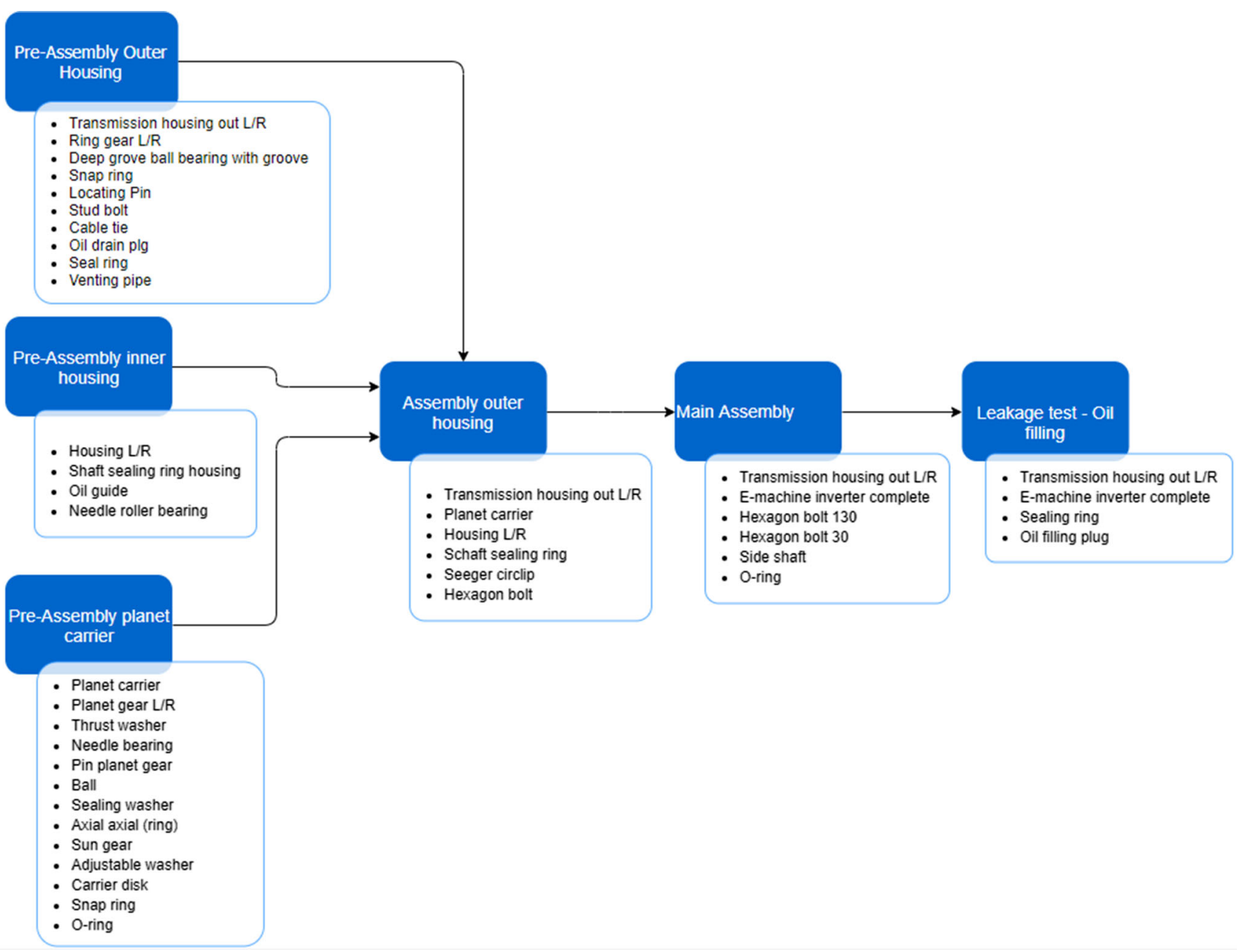

Fig. 1 Structure of the e-axle assembly (type-B)

distributed in the matrix as shown. The implementation of the adaptive technologies must be followed which increases the LoA in the directions shown by the arrows. Finally, this improvement in LoA is measured to determine the increase in cognitive and physical automation.

\subsection{Adaptive assembly concepts}

After the thorough literature review phase, four main concepts were derived. In this section, we will briefly elaborate the concepts being used to make a system adaptive. These concepts are selected, as they are most suitable for ramp-up of high variety, low batch size assembly by achieving adaptability. The technologies that must be implemented must be a well-balanced solution of automated and manual tasks. With this as the focus, the various concepts have been described below in a nutshell.

Migration manufacturing The number of variants of each e-axle is increasing considerably with slight variations. Migration manufacturing helps with a method that can manufacture these different parts on the same assembly line by implementing internal loop lines [11]. The use-case of migration manufacturing with meandering technique has been explained in [11].

Holonic manufacturing system Holonic Manufacturing System (HMS) is a concept used for increasing the flexibility, agility, and reconfigurability of the manufacturing process [12]. Each unit of HMS is represented by an autonomously working unit called holon [13]. A holon is defined in the holonic paradigm as a unit that advocates the use of autonomous and cooperative manufacturing units [12]. These holons can interact and communicate with other holons and build a hierarchy, which in HMS is termed as holarchy [13]. If any assembly station breaks down, a multi-function (MF) station can be utilized to continue the process. The docking station (DS holon) decides whether (and when) to divert the part from the main line in case of a bottleneck and sends a signal to AGV (Autonomous Guided Vehicle) that transports the picked-up part. Hence, 
Fig. 2 LoA matrix

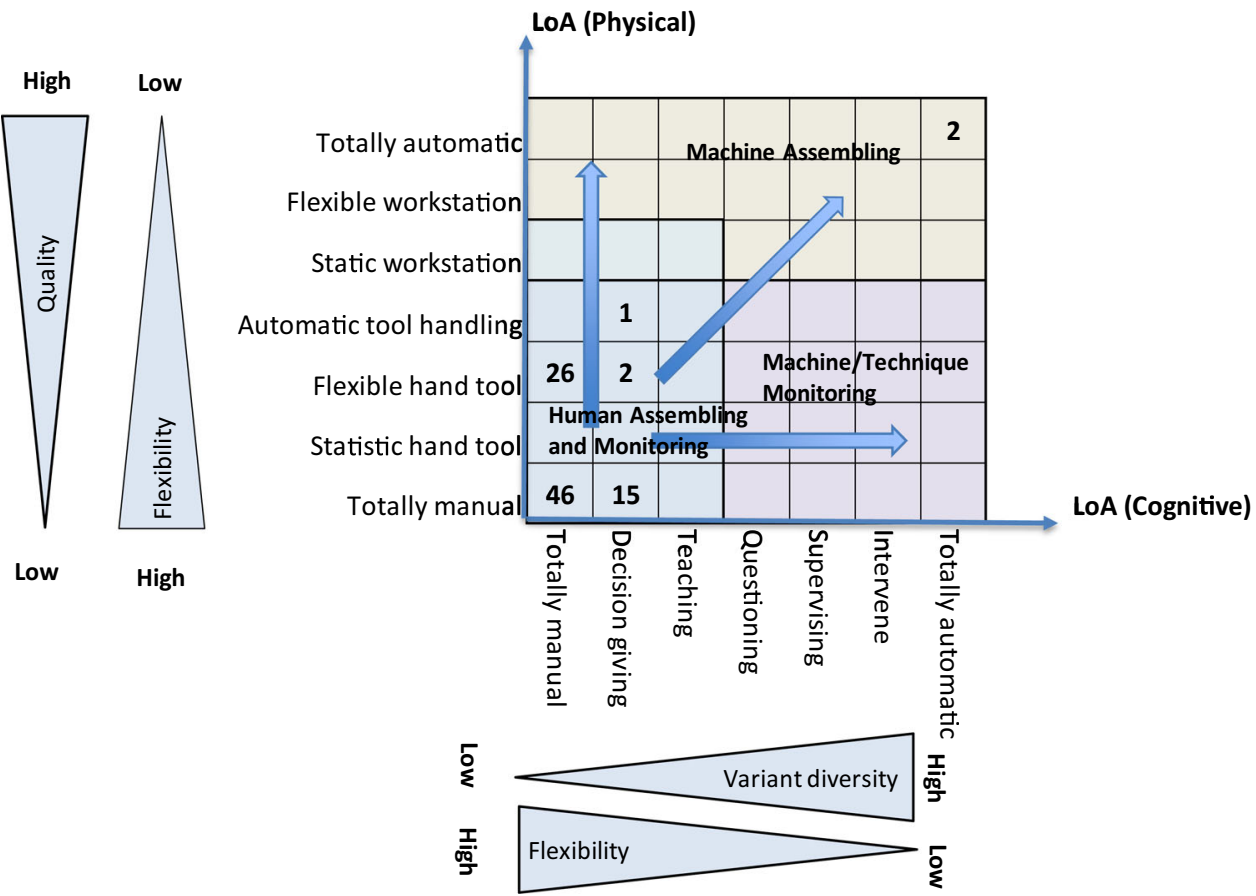

there is coordination between these holons. However, the assembly stations can still be manually operated [12].

Reconfigurable manufacturing system Reconfigurable manufacturing system (RMS) can be defined as an intermediate between DMS and FMS [14]. However, the concept of reconfigurability is applicable for a specific part family of products [2] and customized flexibility [15]. It bridges the gap between the high flexibility and high cost of totally flexible machines and the low flexibility and low cost of fully dedicated machines [16, 17]. Reconfigurability at lower levels such as machines, cells, and shop floors, is achieved by changing the hardware resources [14]. The throughput of RMS is higher than the throughput of FMS, but is lower than that of DMS for the same investment cost [18]. There are six core characteristics and principles that an RMS system can achieve: scalability, convertibility, diagnosability, customization, modularity and integrability [18]. Reconfiguration technologies can be implemented on various aspects of an assembly station such as machine, inspection, system [18] and small assembly stations. This system can also be called as a hybrid system where one can obtain volume flexibility with low investment shown in [7]. The system is economical because the movements are reduced to minimum [7]. Also, the output can be increased as the time required by the worker decreases.

Cognitive factory-HMI (human machine interface) Being cognitive is about flexibility and faster adaption to change. The easy interaction between humans and machine is the key success of a cognitive factory. These are assistance systems that actively support the worker. This also allows automatic knowledge transfer and collaboration between experts and unskilled workers [19]. Sensors and actuators form the main basis of the basic interaction between the assistance systems and humans [20]. As described in [19], this sensor network can be based on initial measurement units (IMUs), cameras and processing units. To simplify the understanding, chosen two functional cases that can be derived include:

- Input/observation techniques: Hand gesture recognition-the movement of hands (such as grasping) can be tracked by the sensors or a camera [21] and this can be integrated with pick-to-light system for high product and component variety [8].

- Output modalities: Head Mounting Devices (HMDs) such as retina display or augmented reality (AR) [22], are suitable. Visual screen at a static position shows the next assembly steps [21]. Text-to-speech system can also be considered as the assembly is noise free [21].

Achieving the right balance between the two dedicated and flexible manufacturing systems by combining the different concepts explained above would be an ideal way of achieving the right flexibility. Each approach that has been studied would ideally fit the assembly line of low volume and high variety of batch production. Hence, an ideal direction is to implement the best aspects of each concept to achieve this flexibility, adaptability, and low costs. Table 2 summarizes the benefits of each concepts.

These concepts focus on one or more core areas of an assembly plant along with their Key Performance 
Table 2 Benefits of each concept

\begin{tabular}{|c|c|c|c|c|}
\hline Parameters & Migration manufacturing & $\begin{array}{l}\text { Holonic } \\
\text { manufacturing } \\
\text { system (HMS) }\end{array}$ & $\begin{array}{l}\text { Reconfigurable manufacturing system } \\
\text { (RMS) }\end{array}$ & $\begin{array}{l}\text { Cognitive factory- } \\
\text { HMI }\end{array}$ \\
\hline Ideal for & Increasing variants $[11]$ & $\begin{array}{l}\text { Flexible and } \\
\text { dynamic allocation } \\
\text { of resources [13] }\end{array}$ & $\begin{array}{l}\text { Quick and easy adjustments to new } \\
\text { products [2] }\end{array}$ & $\begin{array}{l}\text { Increasing } \\
\text { productivity [8] }\end{array}$ \\
\hline $\begin{array}{l}\text { Initial } \\
\text { investment }\end{array}$ & $10-30 \%$ less than FMS [11] & $\begin{array}{l}\text { Higher than DMS, } \\
\text { but lower than } \\
\text { FMS }\end{array}$ & Lower than automated system [7] & $\begin{array}{l}\text { High initial } \\
\text { equipment cost }\end{array}$ \\
\hline $\begin{array}{l}\text { Overall efforts } \\
\text { for } \\
\text { implementing }\end{array}$ & $\begin{array}{l}50-80 \% \text { lesser compared to } \\
\text { individual lines [11] }\end{array}$ & $\begin{array}{l}\text { Higher initial efforts } \\
\text { than DMS }\end{array}$ & Depends on the level of reconfigurability & $\begin{array}{l}\text { Comparatively } \\
\text { lower than RMS } \\
\text { and HMS }\end{array}$ \\
\hline $\begin{array}{l}\text { Other } \\
\text { advantages }\end{array}$ & $\begin{array}{l}\text { Faster break-even point than an } \\
\text { additional line; 5-14\% lesser } \\
\text { variable cost [11] }\end{array}$ & $\begin{array}{l}\text { Increase in } \\
\text { productivity and } \\
\text { throughput [12] }\end{array}$ & $\begin{array}{l}\text { High responsiveness to fluctuating markets } \\
\text { [18]; movements of operator are reduced } \\
\text { to minimum [7] }\end{array}$ & $\begin{array}{l}\text { Pick-to-light can be } \\
\text { used for variety of } \\
\text { tools [8] }\end{array}$ \\
\hline
\end{tabular}

Indicators (KPIs). For example, if "throughput" is considered, the concept of HMS, RMS, and Cognitive Factory achieve this KPI. Likewise, the concept of Migration Manufacturing focusses on the KPI: "Area" and so on. These KPIs form the basis as a requirement of an adaptive assembly for high variety. As shown in Table 3, the concepts focus on four main core areas of the assembly plant which in turn has several KPIs. Marked " $x$ " indicates that the concept targets a specific core area.

\section{Research direction}

With the concepts and their focussing area and KPIs explained, the technologies to execute these concepts must be described. These technologies are clustered based on the features in an assembly plant. These are then categorized by their level of practicality which is explained in the further section. Furthermore, they are evaluated subsequently to depict the adaptability achieved.

\subsection{Derived technologies}

Achieving the maximum adaptability in the assembly process with a high variety of e-axles is the goal of these concepts. Also, another goal is maintaining the right balance between the automated systems and manual work keeping the small volumes, high variety, and finally costs in mind. To enable this adaptability, as shown in Fig. 3, the derived morphological matrix has various technologies based on their Level of Practical Application (LoPA). These technologies can also be classified individually on their Technology Readiness Level (TRL) [23]. This matrix can be served as a building frame for adaptability. The aspects or features tagged with an asterisk (*) are the aspects that are being focussed on for the current assembly type and these aspects have higher practical implications.

\subsection{Evaluation techniques}

The various technologies specified previously are to be implemented and verified with the help of verification

Table 3 Concepts, core areas and their KPIs

\begin{tabular}{|c|c|c|c|c|c|}
\hline \multirow[b]{2}{*}{$\begin{array}{l}\text { Core } \\
\text { area }\end{array}$} & \multirow[b]{2}{*}{ KPIs } & \multicolumn{4}{|l|}{ Concepts } \\
\hline & & $\begin{array}{l}\text { Migration } \\
\text { manufacturing }\end{array}$ & $\begin{array}{l}\text { Holonic manufacturing } \\
\text { system (HMS) }\end{array}$ & $\begin{array}{l}\text { Reconfigurable } \\
\text { manufacturing system } \\
\text { (RMS) }\end{array}$ & $\begin{array}{l}\text { Cognitive } \\
\text { factory-HMI }\end{array}$ \\
\hline Layout & Area $\left(\mathrm{m}^{2}\right)$, design of layout & $\times$ & & & \\
\hline Process & $\begin{array}{l}\text { Throughput, overall equipment } \\
\text { efficiency (OEE), quality }\end{array}$ & & $\times$ & $x$ & $x$ \\
\hline Machine & $\begin{array}{l}\text { Cost, throughput, quality, } \\
\text { performance }\end{array}$ & & $\times$ & $\times$ & $\times$ \\
\hline Logistics & Time, inventory & & $\times$ & & \\
\hline
\end{tabular}




\begin{tabular}{|c|c|c|c|}
\hline $\begin{array}{c}\text { LOPA } \\
\text { (Level of Practical Application) }\end{array}$ & Low & Medium & High \\
\hline Focussing Area & $\begin{array}{l}\text { - Research phase } \\
\text { - Simulation approach * }\end{array}$ & $\begin{array}{l}\text { - Evaluation phase } \\
\text { - Prototype implementation }\end{array}$ & $\begin{array}{l}\text { - Implementation phase } \\
\text { - Applicable in all industries }\end{array}$ \\
\hline Level of Risk & - Very high risks & - Medium to high risks * & -Zero to Low risks* \\
\hline Communication & $\begin{array}{l}\text { - Real-time Wireless } \\
\text { communication, 5G } \\
\text { - Self-organised wireless } \\
\text { networks, Neuronal network }\end{array}$ & $\begin{array}{l}\text { - Wireless communication * } \\
\text { - Holonic communication * }\end{array}$ & $\begin{array}{l}\text { - Real-time bus interfaces } \\
\text { - Mobile networks * } \\
\text { - EMUX and High perf., } \\
\text { communication * }\end{array}$ \\
\hline Sensors & $\begin{array}{l}\text { - Miniaturized sensors } \\
\text { - Smart sensors } \\
\text { - Vibration device* }\end{array}$ & $\begin{array}{l}\text { - Multi sensor fusion } \\
\text { - Networked sensors } \\
\text { - Innovative safety sensors } \\
\text { (fail-safe system) * }\end{array}$ & $\begin{array}{l}\text { - Motion sensors* } \\
\text { - Temperature sensors } \\
\text { - Pressure sensors } \\
\text { - Acceleration sensors }\end{array}$ \\
\hline Actuators & & $\begin{array}{l}\text { - Intelligent actuators } \\
\text { - Networked actuators } \\
\text { - Safety actuators }\end{array}$ & $\begin{array}{l}\text { - Pneumatic grippers in } \\
\text { robot* }\end{array}$ \\
\hline $\begin{array}{l}\text { Human Machine } \\
\text { Interfaces }\end{array}$ & $\begin{array}{l}\text { - Human behaviour model } \\
\text { - Object recognition (YOLO) } \\
\text { - Semantics visualization } \\
\text { - Exoskeleton }\end{array}$ & $\begin{array}{l}\text { - Voice controls } \\
\text { - Gesture controls } \\
\text { - Augmented reality } \\
\text { - Virtual reality * }\end{array}$ & $\begin{array}{l}\text { - Intuitive controls* } \\
\text { - Pick-to-light systems * } \\
\text { - Digital watch/static } \\
\text { screen * }\end{array}$ \\
\hline Layout/Logistics & $\begin{array}{l}\text { - Matrix manufacturing } \\
\text { - Bionic layout structure }\end{array}$ & $\begin{array}{l}\text { - Meandering technique * } \\
\text { - Matrix manufacturing * } \\
\text { - Logistics: Agent based } \\
\text { communication * }\end{array}$ & $\begin{array}{l}\text { - Series/flow/parallel } \\
\text { production, etc. } \\
\text { - Automatic Guided Vehicles } \\
\text { (AGV), AG cart * }\end{array}$ \\
\hline Machine & $\begin{array}{l}\text { - Hybrid Machine } \\
\text { - Additive Manufacturing }\end{array}$ & $\begin{array}{l}\text { - Reconfigurable Machine } \\
\text { System, RM Tools (RMT) * } \\
\text { - Collaborative Robots } \\
\text { (Cobot) * }\end{array}$ & $\begin{array}{l}\text { - Mass Production by } \\
\text { dedicated machines, High } \\
\text { variety \& low volume flexible } \\
\text { manufacturing machines } \\
\text { - Robots, smart tools * }\end{array}$ \\
\hline $\begin{array}{l}\text { Embedded Systems/ } \\
\text { Software }\end{array}$ & $\begin{array}{l}\text { - Industry } 4.0 \text { simulation } \\
\text { - Miniaturized/smart sensors } \\
\text { - Multicriteria situation } \\
\text { awareness } \\
\text { - Artificial Intelligence }\end{array}$ & $\begin{array}{l}\text { - Energy harvesting } \\
\text { - Machine learning } \\
\text { - Digital Twin * }\end{array}$ & $\begin{array}{l}\text { - AutolD technologies } \\
\text { - Big-Data, cloud-computing }\end{array}$ \\
\hline Probable TRL Level & $1-3$ & $4-6$ & $7-9$ \\
\hline
\end{tabular}

Fig. 3 LoPA morphological matrix

models. To help implementing and testing the reliability of the adaptive systems, the recent approaches which are explained further, can be enforced. These techniques help in implementation and verification of the mentioned adaptive concepts.

FMEA The Failure Mode and Effect Analysis (FMEA) is done on the current assembly layout (based on e-axle type-B) to better understand the errors that are occurring during the process [24]. With 92 tasks in the current assembly, the human-led errors during the assembly are studied and a thorough analysis of the severity, occurrence and detection is done. The values of these parameters are provided from the plant managers, as they have an overview of the manifestation of these errors. Table 4 describes some of the general errors that occur along with their RPNs (Risk Priority Numbers). After the implementation of adaptive technologies, the FMEA is done to determine the reduced RPN. Therefore, it indicates the reduction in errors by implementing adaptive technologies.

Simulation model Currently, the assembly process is completely manual with high process times and this has been implemented in the assembly model in Plant Simulation tool. The simulation model helps in determining the bottleneck and the process steps. A bottleneck is defined as a workstation limiting the production efficiency of the entire process [25]. The simulation model allows to calculate the effectiveness of various methods and processes (such as HMI, RMS, etc.) and for a variety of e-axles. The 
Table 4 FMEA analysis of current process

\begin{tabular}{|c|c|c|c|c|c|c|}
\hline Process step/input & Potential failure mode & $\begin{array}{l}\text { SEVERITY } \\
(1-10)\end{array}$ & Potential causes & Occurrence & $\begin{array}{l}\text { Detection } \\
(1-10)\end{array}$ & RPN \\
\hline $\begin{array}{l}\text { Information/assembly } \\
\text { operations }\end{array}$ & $\begin{array}{l}\text { Poor or missing } \\
\text { documentation- } \\
\text { process description }\end{array}$ & 9 & $\begin{array}{l}\text { Huge rework and additional times that } \\
\text { causes unknown expenses }\end{array}$ & 9 & 2 & 162 \\
\hline $\begin{array}{l}\text { Assembly } \\
\text { operations/manufacturing } \\
\text { operations }\end{array}$ & Operating errors & 7 & $\begin{array}{l}\text { Negligence, unskilled or unqualified, } \\
\text { or no presence of mind }\end{array}$ & 8 & 6 & 336 \\
\hline $\begin{array}{l}\text { Assembly operations/ } \\
\text { information }\end{array}$ & $\begin{array}{l}\text { Longer assembly times } \\
\text { than allocated }\end{array}$ & 9 & Missing or unclear workflow structure & 10 & 6 & 540 \\
\hline \multirow[t]{2}{*}{$\begin{array}{l}\text { Person related/assistive } \\
\text { operations/information }\end{array}$} & $\begin{array}{l}\text { Distraction of the } \\
\text { worker }\end{array}$ & 7 & No presence of mind & 7 & 6 & 294 \\
\hline & $\begin{array}{l}\text { Wrong decisions for } \\
\text { basic worker } \\
\text { operations }\end{array}$ & 9 & $\begin{array}{l}\text { Due to lack of management } \\
\text { experience and management skills } \\
\text { or improper recruiting }\end{array}$ & 7 & 3 & 189 \\
\hline $\begin{array}{l}\text { Ergonomics/assistive } \\
\text { operations/information }\end{array}$ & $\begin{array}{l}\text { Lack of prevention } \\
\text { measures }\end{array}$ & 8 & No fixed monitoring techniques & 3 & 5 & 120 \\
\hline \multirow[t]{2}{*}{ Maintenance } & Equipment failure & 9 & $\begin{array}{l}\text { Due to Equipment aging or lack of } \\
\text { testing and maintenance }\end{array}$ & 8 & 5 & 360 \\
\hline & $\begin{array}{l}\text { Wrong tools, broken } \\
\text { tools, missing aids }\end{array}$ & 7 & Increase in assembly times & 6 & 6 & 252 \\
\hline Quality & $\begin{array}{l}\text { Error in quality } \\
\text { inspection }\end{array}$ & 8 & No fixed inspection methods & 7 & 6 & 336 \\
\hline
\end{tabular}

creation of simulation model is done by using a seven-step approach as described by Law [26]. The computer simulation models can be freely improved and further simulations to the improved processes can also be applied freely [27].

The implementation was done as per the layout and station timings. The bottlenecks were clearly seen from the statistic graphs derived from the plant simulation. Furthermore, the changes (adaptive technologies) are also implemented in the simulation tool to determine the increase in throughput and efficiency of the system. Also, with the help of simulation tool, the errors during the rampup production are considerably reduced [27]. Further, a simulation model can be used to visualize in real time and focus on the affecting parameters [27]. This approach can also be linked to the concept of digital twin [28].

Other approaches There are various other methodologies that are being done to determine the priority of each concept. Also, further steps of DYNAMO ++ methodology as described in [8] will be done. The cost-benefit analysis is done to improve the process performance. For example, a pairwise comparison will be done for various adaptive technologies, an FMEA depicting the benefits of each adaptive concept, and finally a cost-benefit analysis.

\section{Expected results}

The adaptive technologies characterized in the research gap would be implemented to the current manual assembly thereby making it adaptive. The described verification models would focus on examining the adaptability of the assembly process. It could also lead to the integration of reconfigurable assembly machines for high variety with human machine interfaces. Another benefit of building an adaptive assembly is the increase in quality or decrease in the current manual errors. This has been illustrated by the FMEA. Furthermore, by implementing these techniques, the costs of complex machines are relinquished. Hence, this would form a basis for achieving a high variety errorfree production.

Acknowledgements Open access funding provided by Graz University of Technology. The authors gratefully acknowledge the support from Pro ${ }^{2}$ Future GmbH. Pro2Future is funded as part of the Austrian COMET Program-Competence Centers for Excellent Technologies - under the auspices of the Austrian Federal Ministry of Transport, Innovation and Technology, the Austrian Federal Ministry for Digital and Economic Affairs, and the Provinces of Upper Austria and Styria. COMET is managed by the Austrian Research Promotion Agency FFG.

Open Access This article is licensed under a Creative Commons Attribution 4.0 International License, which permits use, sharing, adaptation, distribution and reproduction in any medium or format, as long as you give appropriate credit to the original author(s) and the 
source, provide a link to the Creative Commons licence, and indicate if changes were made. The images or other third party material in this article are included in the article's Creative Commons licence, unless indicated otherwise in a credit line to the material. If material is not included in the article's Creative Commons licence and your intended use is not permitted by statutory regulation or exceeds the permitted use, you will need to obtain permission directly from the copyright holder. To view a copy of this licence, visit http://creativecommons. org/licenses/by/4.0/.

\section{References}

1. Ko, J., Hu, S. J., \& Huang, T. (2005). Reusability assessment for manufacturing systems. CIRP Annals - Manufacturing Technology. https://doi.org/10.1016/S0007-8506(07)60062-6.

2. Abou-El-Hossein, K. A., Theron, N. J., \& Ghobashy, S. (2015). Design of machine tool based on reconfigurability principles. Applied Mechanics and Materials. https://doi.org/10.4028/www. scientific.net/amm.789-790.213.

3. Mehrabi, M. G., Ulsoy, A. G., Koren, Y., \& Heytler, P. (2002). Trends and perspectives in flexible and reconfigurable manufacturing systems. Journal of Intelligent Manufacturing. https://doi. org/10.1023/A:1014536330551.

4. Sugiarto, I., Axenie, C., \& Conradt, J. (2016). From adaptive reasoning to cognitive factory: bringing cognitive intelligence to manufacturing technology. International Journal of Industrial Research and Applied Engineering. https://doi.org/10.9744/jirae. 1.1.1-10.

5. Marcel Schwartz, M. S., Dominik Kolz, M. S., \& Katharina Heeg, M. A. (2016). „Dienstleistungsinnovationen für Elektromobilität - Förderung von Innovation und Nutzerorientierung “. Amsterdam. Retrieved from http://www.elektromobilitaet-diens tleistungen.de/?p=3307.

6. Electric Car (Market) Data. (2018). https://evobsession.com/elec tric-car-sales/. Retrieved from https://evobsession.com/electriccar-sales/.

7. Wiendahl, H. P., ElMaraghy, H. A., Nyhuis, P., Zäh, M. F., Wiendahl, H. H., Duffie, N., et al. (2007). Changeable manufacturing-Classification, design and operation. CIRP Annals Manufacturing Technology. https://doi.org/10.1016/j.cirp.2007. 10.003 .

8. Fasth-Berglund, Å., \& Stahre, J. (2013). Cognitive automation strategy for reconfigurable and sustainable assembly systems. Assembly Automation. https://doi.org/10.1108/AA-12-2013-036.

9. Fasth, A., Bruch, J., Dencker, K., Stahre, J., Mårtensson, L., \& Lundholm, T. (2010). Designing proactive assembly systems (ProAct)-Criteria and interaction between automation, information, and competence. Asian International Journal of Science and Technology in Production and Manufacturing Engineering (AIJSTPME), 2(4), 1-13.

10. Lotter, B., \& Wiendahl, H.-P. (2008). Changeable and reconfigurable assembly systems. In H. ElMaraghy (Ed.), Changeable and reconfigurable manufacturing systems. London: Springer. https://doi.org/10.1007/978-1-84882-067-8_7.

11. Meichsner, T. P. (2008). Migration manufacturing-A new concept for automotive body production. In H. ElMaraghy (Ed.), Changeable and reconfigurable manufacturing systems. London: Springer. https://doi.org/10.1007/978-1-84882-067-8_21.

12. Bussmann, S., \& Sieverding, J. (2001). Holonic control of an engine assembly plant: An industrial evaluation. In 2001 IEEE international conference on systems, man and cybernetics. $e$ Systems and e-Man for cybernetics in cyberspace (Cat. No. 01CH37236) (Vol. 1, pp. 169-174). IEEE.
13. Gräßler, I., \& Pöhler, A. (2017). Implementation of an adapted holonic production architecture. Procedia CIRP. https://doi.org/ 10.1016/j.procir.2017.03.176.

14. Bi, Z. M., Lang, S. Y. T., Shen, W., \& Wang, L. (2008). Reconfigurable manufacturing systems: The state of the art. International Journal of Production Research. https://doi.org/10. 1080/00207540600905646.

15. Koren, Y., \& Shpitalni, M. (2010). Design of reconfigurable manufacturing systems. Journal of Manufacturing Systems. https://doi.org/10.1016/j.jmsy.2011.01.001.

16. Katz, R. (2007). Design principles of reconfigurable machines. International Journal of Advanced Manufacturing Technology. https://doi.org/10.1007/s00170-006-0615-2.

17. Abele, E., Liebeck, T., \& Wörn, A. (2006). Measuring flexibility in investment decisions for manufacturing systems. CIRP Annals - Manufacturing Technology. https://doi.org/10.1016/S00078506(07)60452-1.

18. Koren, Y., Gu, X., \& Guo, W. (2018). Reconfigurable manufacturing systems: Principles, design, and future trends. Frontiers of Mechanical Engineering. https://doi.org/10.1007/s11465-0180483-0.

19. Gorecky, D., Worgan, S. F., \& Meixner, G. (2011). COGNITO: A cognitive assistance and training system for manual tasks in industry. In Proceedings of the 29th annual European conference on cognitive ergonomics. https://doi.org/10.1145/2074712. 2074723.

20. ElMaraghy, H. A. (Ed.). (2008). Changeable and reconfigurable manufacturing systems. Springer Science \& Business Media.

21. Wallhoff, F., Wiesbeck, M., Buchta, S., Rigoll, G., AblaBmeier, M., Rauschert, A., \& Bannat, A. (2007). Adaptive human-machine interfaces in cognitive production environments. In 2007 IEEE international conference on multimedia and expo (pp. 2246-2249). IEEE. https://doi.org/10.1109/icme.2007.4285133.

22. Funk, M., \& Schmidt, A. (2015). Cognitive assistance in the workplace. IEEE Pervasive Computing. https://doi.org/10.1109/ MPRV.2015.53

23. Böckenkamp, A., Mertens, C., Prasse, C., Stenzel, J., \& Weichert, F. (2016). A versatile and scalable production planning and control system for small batch series. In S. Jeschke, C. Brecher, H. Song, \& D. Rawat (Eds.), Industrial internet of things (pp. 541-559). Cham: Springer. https://doi.org/10.1007/978-3-31942559-7_22.

24. Pascu, C. I., \& Paraschiv, D. (2016). Study about improving the quality process performance for a steel structures components assembly using FMEA method. Applied Mechanics and Materials. https://doi.org/10.4028/www.scientific.net/amm.822.429.

25. Betterton, C. E., \& Silver, S. J. (2012). Detecting bottlenecks in serial production lines-A focus on interdeparture time variance. International Journal of Production Research. https://doi.org/10. 1080/00207543.2011.596847.

26. Law, A. M. (2009). How to build valid and credible simulation models. Proceedings - Winter Simulation Conference. https://doi. org/10.1109/WSC.2009.5429312.

27. Kikolski, M. (2016). Identification of production bottlenecks with the use of plant simulation software. Engineering Management in Production and Services. https://doi.org/10.1515/emj-2016-0038.

28. Zhuang, C., Liu, J., \& Xiong, H. (2018). Digital twin-based smart production management and control framework for the complex product assembly shop-floor. International Journal of Advanced Manufacturing Technology. https://doi.org/10.1007/s00170-018$1617-6$.

Publisher's Note Springer Nature remains neutral with regard to jurisdictional claims in published maps and institutional affiliations. 

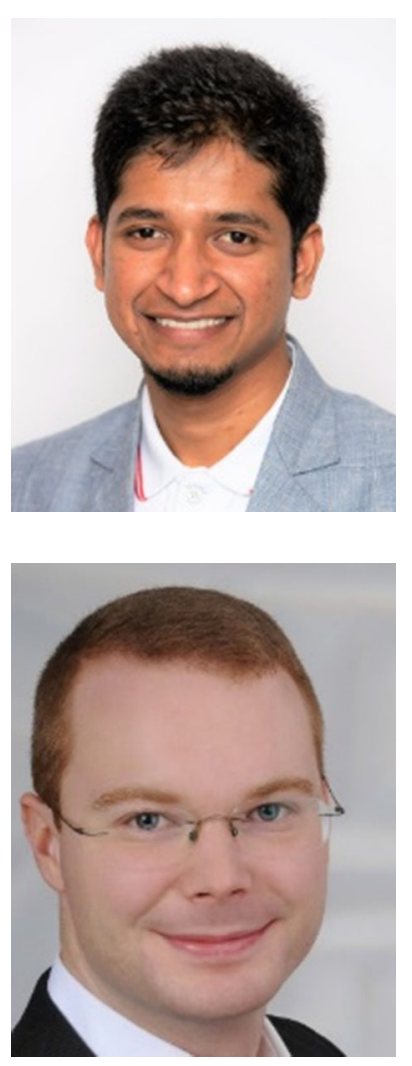

Muaaz Abdul Hadi is currently working as a researcher and a doctoral student at Pro2Future $\mathrm{GmbH}$ and Graz University of Technology respectively. His focus area is Cognitive Production Systems.

Markus Brillinger is currently working as a senior researcher at Pro2Future $\mathrm{GmbH}$ and at AVL List. His focus area is Cognitive Production Systems and e-mobility.

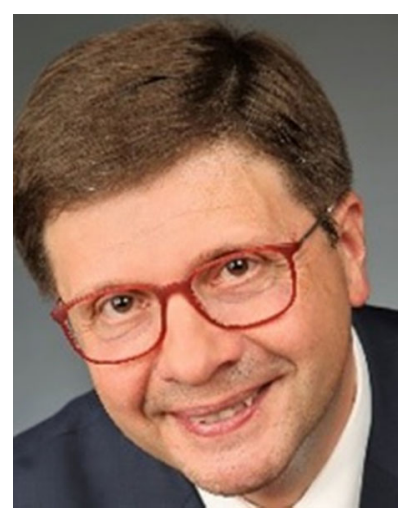

Franz Haas is a key scientific partner at Pro2Future $\mathrm{GmbH}$ and the dean of mechanical studies at Graz University of Technology.

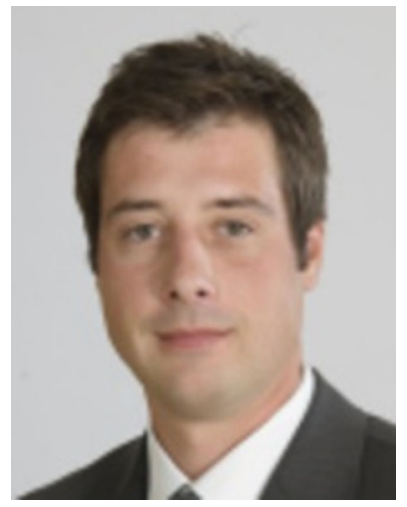

Martin Weinzerl is an associate from scientific partner, AVL List. His focus area is e-mobility. 